\title{
Religious Human Resources Management: Perichoresis to manage or to be managed?
}

\author{
Halim Wiryadinata* \\ Sekolah Tinggi Teologi Pelita Bangsa, Indonesia \\ Email: halimwiryadinata@sttpb.ac.id
}

\begin{abstract}
The meaning of the Greek word, which is Perichoresis as co - indwelling or co - inherence in the sight of the Trinity as the dogma of Christian has a broader perspective of mutual interpenetration of Beings. Thus, it leads the author to argue that Perichoresis is terminus technicus in assessing the management of people (Human Resources Management and People Development) to synergize the jobs for maintaining and achieving the goal of the company. Thus, there are three mainstreams of this article, which are: Firstly, I will look at the history of Perichoresis as a terminus technicus; Secondly, I will explore Human Resources Management and People Development as the parallel of Perichoresis; and Lastly, I will construct a concept of Perichoresis as terminus technicus in Human Resources Management and People Development to achieve the vision of the company.
\end{abstract}

Keywords: Perichoresis, HRM, Human Resources Management, Religious.

\section{INTRODUCTION}

The slowing down of economy (or intending to the global economic crisis) in the world today, we can see one of the factors, in causing it, is that the speculative financial market and its impact on the economy of the country. It is also added with the tension between the Western superpower (the United States of America) and the Eastern superpower (The Republic of China) in implementing the international tariff on certain commodities when enter their countries. Instead of serving the global economy, this market contributes the worse condition of relationships among the goods, services, environment, as well as human capital, have become subordinated and manipulated by speculative capital seeking to maximize profits. Grochmal (2016) sees to maximize profits is the central aim, not between the employer and the employee, but it is further beyond the world of work and the world of finances (Stanisław Grochmal, 2016). If this is so, then it will create the destruction between economy and social relationship - where human resources become the 'slave of profit-oriented' for the speculative capital (Stanisław Grochmal, 2016). In other words, the profit-oriented of the speculative capital devastates the relationship between market and business environment. It leads to Pitelis to see that "efficiency and productivity can be the biggest foes of efficiency and productivity" for the global economic crisis today (Pitelis, 2002). It needs to change the concept of the unlimited greedy of shareholders leads to inequitable distribution of income, unemployment and environmental disaster to the need of mentality and a new paradigm in management human resources based on spirituality.

The shifting paradigm of the managers, according to Bruni (2002) in business today is to focus on the implementation of spirituality in management from the concentrating material into immaterial, hardware to software and capital to knowledge (Bruni, 2002). So, to say the new paradigm is reducing the importance of material value in the interest of spiritual value becoming a new concept of human resources 
management and people's development. To help the poor, the equality of income, and the increasing of GDP are the main focused for management by implementing a spirituality-based program.

\section{RESEARCH METHOD}

This research is taking the qualitative method using the interpretative as the mean of interpreting the movement of the past arguments concerning theology (trinity) and human resources management. The philosophical worldview also is conducted through this research, which is the post-positivism philosophy to show the holistic of arguments in the social dimension to conclude of the research. The postpositivism leads to the epistemological concept, which is to construct the idea between theology and human resources management in the term of theological concept (Crotty, 1998, 39-40). The interpretative for this method will open us to see the possible agreement between Theology and Management. This interpretative also gives us to see the history of Perichoresis and the interpretation from the original founding fathers. Then, the interpretation will be forwarded to see how the interpretation of trinity as the administration and management in the light of human resources management. Then, the connection of those should be seen from this approach.

Perichoresis is taken from two Greek words, the preposition 'peri', which means 'around' and the verb 'choreo', which means 'to give way'. This word does not state in the Bible, but it is used for terminus technicus for explaining the state of Being of the Holy Trinity in the Christian doctrine. Therefore, Perichoresis could be translated as 'rotation' or going around' as lexically meaning. This word is to explain Trinity in the logical way by treating it as the mutual intersecting or interpenetration of the three Persons of the Godhead and may help clarify the concept of Trinity. The word of Perichoresis also is to refer the community of being in which each person penetrates the other and is penetrated by them. Above all, Perichoresis should be considered as the penetration and indwelling of the three divine persons equally in one another.

\section{RESULTS AND DISCUSSION}

\section{Perichoresis as God's management}

Artemi (2017) looks at the word of perichoresis is rendered as a Greek term used to describe the triune relationship between each person of the Godhead (Artemi, 2017; Crump, 2006; Stamatoviĉ, 2016). That word was used in the beginning by the Cappadocian fathers, pseudo - Cyril of Alexandria, Leontius Byzantius and Maximus the Confessor to show the trinitarian and Christological theology. It can be defined as co - indwelling or co - inhering in the relationship of the Triune God especially between the Father and the Son. Eirini Artemi (2017) points outs that August Deneffe argues that perichoresis has relationship with the Stoic concept of mixture, which means a mutual interpenetration of two substances that preserve the identity and property of each intact (Artemi, 2017).

From what it has been said above, it leads us to see that perichoresis does not appear on the text of the New Testament theology, but it is the expression of Scripture to see that the Son is in the Father and the Father is in the Son in the Johannine Gospel and the other part in the Jesus' prayer: "Father, the hour has come. Glorify your Son, that your Son may glorify you". On the other verse also, Jesus says that the Holy Spirit glorifies me. This verse implies that the Holy Spirit glorifies the Father and the Son as long as Jesus is in the Father and the Father is in Jesus. Thus, this perichoresis is the fellowship of three persons mutually 
indwell one another in a dynamic communion, but they are in the same essence whereas distinct hypostatic attributes (Stamatoviĉ, 2016).

The penetration of Stoic philosophy to the Christian theology on perichoresis is terminus technicus to express the mutual interpenetration of the three hypostases of Triune God in continuous existence in divine life to show the Hypostatic Union in Christ through the personal Being and the finite human into the substantial communion in the Godhead (Artemi, 2017). In other words, the terminus technicus on perichoresis is the relationship of the members of the Trinity in the Godhead. It implies the role of each personal Being has its own role and each personal Being never takes over one another. On this basis, the Father, the Son and the Holy Spirit are distinct persons, without making any of them is inferior to the other. The Father conceives the plan of creation, the Son makes the Father's plan become reality and the Spirit leads the Father's plan to its perfection and glorification.

Grochmal also sees that the word of perichoresis maintains the unity in the spirituality from the diversity, so despite different status and social situation, perichoresis unites the diversity in one. Then, he goes on to say that the concept of perichoresis signifies "the two realities can exist one within one another, without confusing them and maintaining (an even better in a certain way) their proper identity: the united without confusion and distinct without being divided"(Grochmal, 2016, 8). Therefore, perichoresis is terminus technicus to understand the distribution of jobs without interfering one another and the distribution of power exists equally.

The perichoresis as terminus technicus shows the paradigm of unity in the Trinity concept of Christian dogma. As it is said above, the perichoresis displays the charism of unity in the Godhead and implies the spiritualty of unity when John 17 says, "Holy Father...may all be one as You and I are one." The main implementation of perichoresis on the basis of the textual religious scripture is to see mainly practice - oriented in spirituality of unity in the Godhead and be applied into the management of human resources. In particular term, perichoresis exposes separate Being in the Godhead to be brought together in harmony or unity in diversity in the management of saving work for human beings.

\section{HRM: Manage or to be Managed?}

Goals and objective of the company or organization can be achieved through the best co - ordinated effort of their members. The process of management and decision making of work are needed the effective management for the essential success for the management. In other words, management can be regarded as: taking place within organizational setting with prescribed roles, directed toward the aim, achieved goals through people, and using procedures and system (Mullins, 2016).

The work of Schneider and Barsoux explore the meaning of management is taken from the differences in beliefs and values (S. C. Schneider \& Barsoux, 2003). In other words, the influence of culture makes management to be significant feature to be success in the world of business. To perform successful in the global economy, managers should understand the effects of the different cultures on the organizational behavior (A. M. Francesco \& Gold, 2005). Thus, the principle of management is related with the human resources, who work together in co - ordinated effort to achieve the goals. Human resources are the main element to make the goals achievable, but they need to be in harmonious work. In concrete term, the principles of human resources management should have division of work, authority, responsibility, unity of command and direction to achieve the company's goals and objectives (Mullins, 2016). 


\section{Figure 1: Managerial work (Mullins, 2016)}

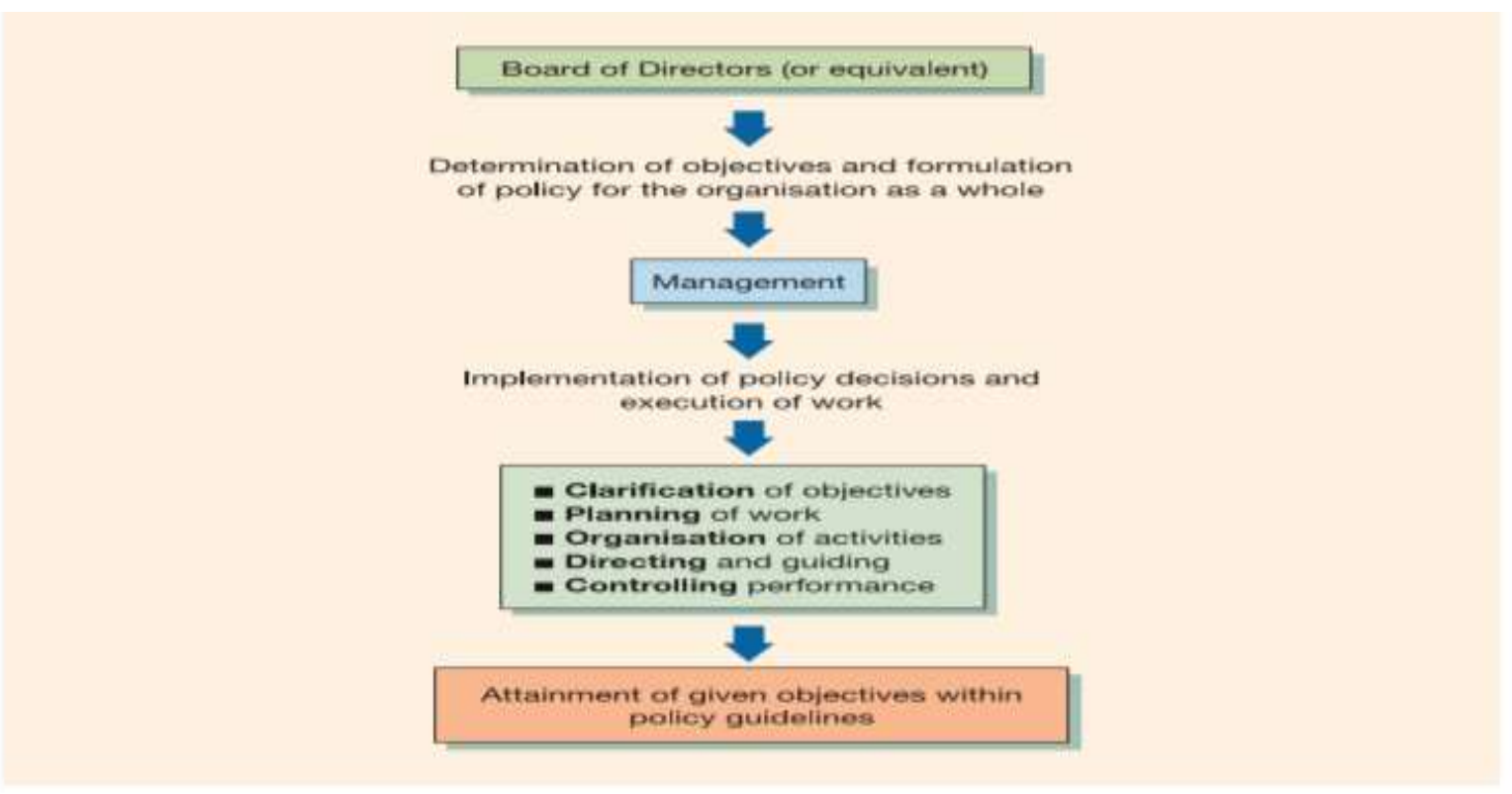

Figure 1 pictures the flow of management's work from the top level to attain the company's objective through human capital or resources management. Thus, human capital is very important element to attain the goals of company through the clarification and division of work, unity of direction, and command in the strategic of human resources management. Focusing on the quality, customer service, productivity, employee involvement, teamwork and workforce flexibility is needed in the strategic human resources management to attain the company's goals and objectives.

From what it has been said above, it follows to see how human capital achieves the company's goals and objective through the people development. The people development program on the human resources management is based on the competency and talent based. The approach for the development of human resources is extended from the competency to the talent based in order to recruit, hire and develop employees to get the superior workforce (Claus, 2019; Meyers, 2019). Put it in differently, the people development through competency and talent based should have a clear job descriptions to have clarification of division of work, unity of command and unity of direction to accomplish the company's goals and objectives.

The parallelism of management of human resources and perichoresis can be seen from the division of jobs, unity of command and unity of direction in Godhead and company. As it is stated above, the dogma of trinity in Christian theology shows the idea of division of jobs in the Beings in redeeming people in the history of salvation, while the strategic management of human resources contains the idea of division to achieve the objective of company to gain the profit (Biela, 2006; Stanislaw Grochmal, 2016). This parallelism certainly only work in the human values, because the objectification of the two big polar is rendered in the human values to reach the goals or objectives. In other words, the human values become the basic element of making the two big polar possible and create the homo spiritualis as a new model of manager and employee in the human resources management and people development.

The work of Daromir Rudnyckyj pictures how the spiritual economies creates the development of employees to compete in the globalization through the ESQ training (Rudnyckyj, 2010). Rudnyckyj has approached his work through the Weberian assumption, which is religion can enter into the economic 
development process as facilitating input as source of methodology, behavior and practice. Nonetheless, Rudnyckyj also depends heavily on the work of Foucault to support his view that economic success and spiritual development are mutual beneficial to achieve the highest productivity. He brings us to see the reflection for a transformation of spiritual reform with the intervention designed to address the economic crisis, which happened in Indonesia at the late of 1990s (Rudnyckyj, 2010). In other words, the work of Rudnyckyj is the marital of methodologies of Webber and Foucault to be the answer of spiritual economies and his study falls into the interdisciplinary study of religion in the age of global economics. This is actually the concept of Foucault on the notion of spiritual economy as a form of governmentality (Rudnyckyj, 2010).

Focusing the idea of Rudynckyj, the management of human resources and people development introduces the idea of spiritual unity as the terminus technicus to take spirituality as the higher level of achievement from the knowledge. This level characterizes a human, who perceives the reality in immanent and transcendence perspective, one who is bound for realization of the common good and building relationship with others, whereas economic and management consider such values as mutual love, friendship, solidarity, and gratuitous gift as fields of implementation. Homo spiritualis is named for the developing people toward to the goals (Stanisław Grochmal, 2016). Figure 2 explains the idea of the perichoresis, where it works together in achieving the objective of humanity especially for the salvation. Therefore, this idea represents how the perichoresis leads the idea of human resources management in achieving the objective of organization through the work of stakeholders.

\section{Figure 2: Perichoresis Work}

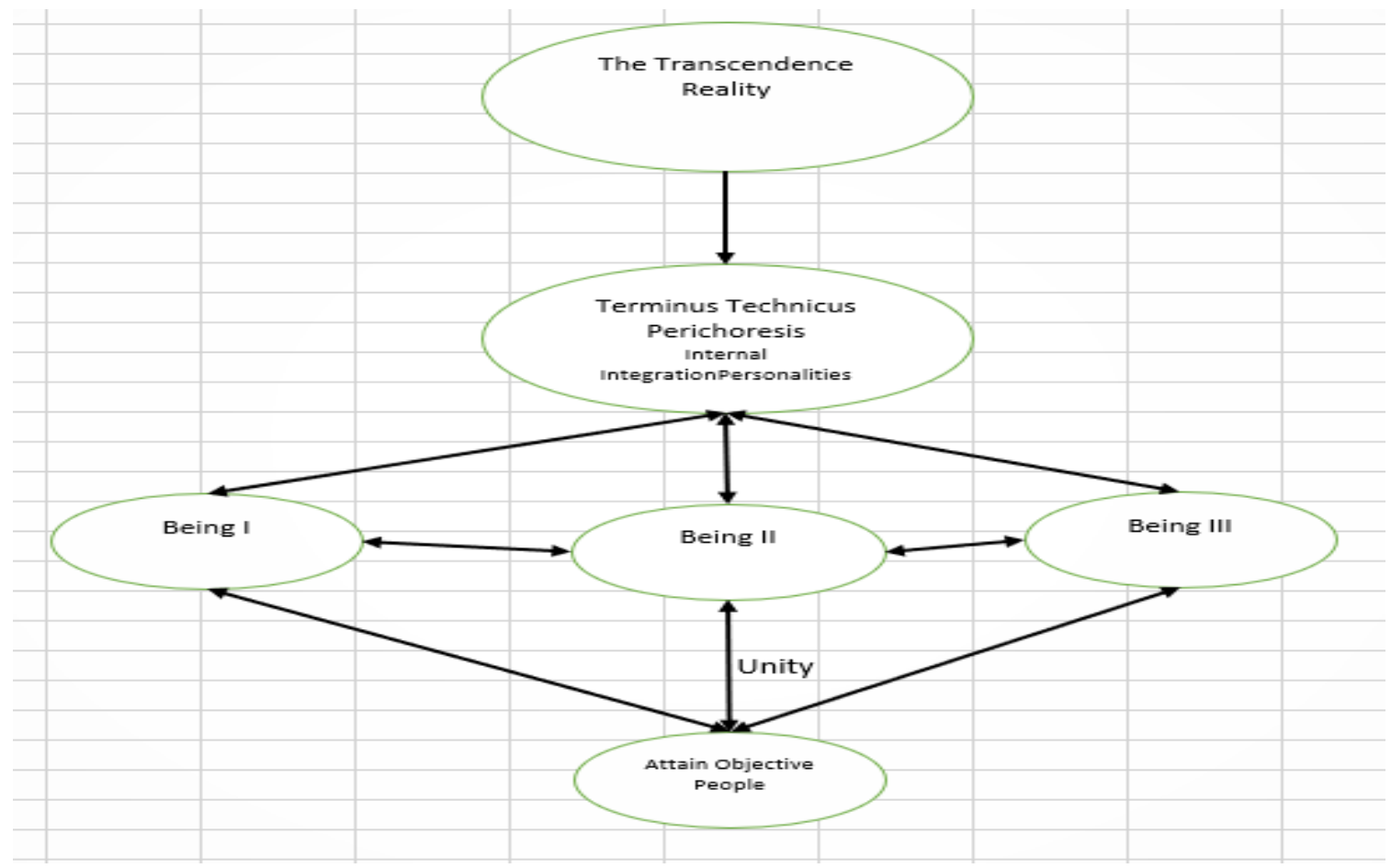




\section{Construction of Perichoresis in HRM}

Giorgio Agamben, The Kingdom and The Glory, builds up the concept of oikonomia in the doctrine of the Godhead (Agamben, 2011). Agamben starts his arguments through his archeological investigation into the economic theology to consider the articulation of two different polarities and, at the end, constitutes what he calls 'governmental machine' (Giorgio Agamben, 2011, 1). By two polarities, he means that the transcendental pole of sovereignty and the immanent pole of the administration, the Kingdom and the Glory. He goes on to say, "Political theology, which founds the transcendence of sovereign power on the single God, and economic theology, which replaces this transcendence with the idea of an oikonomia, conceived as immanent ordering - domestic and political in strict sense - of both divine and human life. Political philosophy and the modern theory of the sovereign derive from the first paradigm; modern biopolitics up to the current triumph of economy and government over every other aspects of social life derive from the second paradigm" (Giorgio Agamben, 2011,1).

In responding to Giorgio Agamben, the idea of economic Trinity is the same idea of immanent Trinity in the head of Karl Rahner (Karl Rahner, 1970). Even, Karl Rahner makes his famous saying in trinitarian pronouncement, "The economic Trinity is the immanent Trinity and the immanent Trinity is the economic Trinity"(Rahner, 1970; Sanders, 2001). Nevertheless, the concept of perichoresis leads us to see that the trinitarian dogma is rooted in the solid ground of salvation of history in humanity, where the economic Trinity is the same as the immanent Trinity. If this is so, it can be applied to the management, where the end of the objective in a company is attainment of objective. Due to the same application and implication, then the construction perichoresis concept in the human resources management and people development is based on the human values such as mutual love, friendship, solidarity, and gratuitous gift in the unity of spirituality.

Thus, whatever the orientation of individual to work, the nature of organization and the cultural influences, it is through the process of management that every effort of the members of the organizations are co - ordinated, directed and guided towards to the achievement of the goals (Mullins, 2016). In other words, management is an integrating activity between the individual and the organization and this requires the understanding of both human personality and work organization. Mullins insets the relationship in the term of philosophical ontology perichoresis strongly says, "It is essentially an integrating activity that permeates every facet of the organization's operations and should serve to reconcile the needs of people at work with the requirements of the organization" (Mullins, 2016, 10). So to say, in reflecting the figure 1 and figure 2 above, management should create the right balance between inter - related elements that make up the total organization and to weld these into coherent patterns of activity in which the organization is operating in the harmony of the Godhead (perichoresis).

In constructing the human resources management and people development, perichoresis as terminus technicus signifies basic managerial philosophies to make management effective towards the company's goals or objectives. The basic managerial philosophies should manage with and through people to ataint the goals by respect \& trust, recognition \& credit, fair \& equitable treatment, and staf \& customer satisfaction (Mullins, 2016). 


\section{Basic Managerial Philosophies}

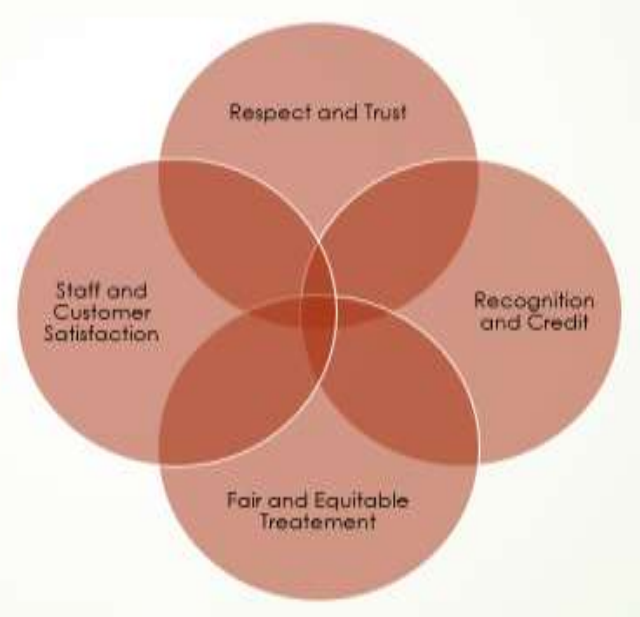

Figure 3 creates the idea how religious human religious management is bound of the values of human resources management. This forms the values, where human resources management reflects the idea of religious values as the founding elements to establish the merit of religious human resources management such as:

1. Respect \& Trust: the initiative of respect and trust must come from management to get the feedback from the employees. If the management treats little, then you get a little. The majority of employees are treated respectively based on trust; responsible individuals serve the organization well.

2. Recognition \& Credit: managers should praise with genuine recognition and credit to the employees when they achieve specific task and develop their talents according to their competency via training or schooling.

3. Fair and Equitable Treatment: management should treat employees on the basis of merits and justice in treatment with a clear policy of human resources by avoiding the discrimination.

4. Staff \& Customer Satisfaction: satisfaction is a good manager, because manager - subordinates relationship can be harmonious to create a working environment to achieve the highest level of objective and manager should gain the highest spirit of employees for mutual co - operation in order to get the motto 'working with manager, not working for manager'.

\section{CONCLUSION}

To conclude, the Christian term perichoresis in the Godhead as terminus technicus displays the harmonious indwelling of the Beings without any disruption one another. Each Being has own job stated in the 'job description' in the textual religious scripture to achieve the goals based on the salvation history 
for human beings. This, as a result, applies smoothly into management of human resources and people development with the construction of human resources management and people development with stated above managerial principles of philosophies. To manage and to be managed are equally in the form of management and God's saving work in leading people towards to the goals.

\section{REFERENCES}

A. M. Francesco, \& Gold, B. A. (2005). International Organizational Behavior (2nd ed.). New Jersey: Prentice Hall.

Agamben, G. (2011). The Kingdom and The Glory (1st ed.). California: Stanford University Press.

Artemi, E. (2017). The Term Perichoresis from Cappadocian Fathers to Maximus Confessor [1] 2 . Trinitarian Context of the Perichoresis from Cappadocian Fathers to Maximus Confessor. International Journal of European Studies, 1(1), 21-29. https://doi.org/10.11648/j.ijes.20170101.14

Biela, A. (2006). A Paradigm of the Unity in Social Sciences. Journal for Perspective of Economic, Political and Social Integration, 17, 167-177.

Bruni, L. (2002). The Economy of Communion: Toward a multidimensional economic culture (spirituality of unity) (L. Bruni, Ed.). New York: New City Press.

Claus, L. (2019). HR disruption-Time already to reinvent talent management. BRQ Business Research Quarterly, 22(3), 207-215. https://doi.org/10.1016/j.brq.2019.04.002

Crotty, M. (1998). The Foundation of Social Research. New South Wales: Allen \& Unwin.

Crump, D. (2006). Re-examining the Johannine Trinity: Perichoresis or deification? Scottish Journal of Theology, 59(4), 395-412. https://doi.org/10.1017/S0036930606002547

Grochmal, Stanislaw. (2016). The Paradigm of Unity in the Science and Culture. Journal for Perspectives of Economic Political and Social Integration, 22(1-2), 41-72. https://doi.org/10.1515/pepsi-2016-0002

Grochmal, Stanisław. (2016). Spirituality of unity in management - Economy of Communion. Cogent Business and Management, 3(1), 1-18. https://doi.org/10.1080/23311975.2016.1140618

Meyers, M. C. (2019). The neglected role of talent proactivity: Integrating proactive behavior into talent-management theorizing. Human Resource Management Review, 30(2), 1-13. https://doi.org/10.1016/j.hrmr.2019.100703

Mullins, L. J. (2016). Management \& Organisational Behaviour. Harlow: Pearson Education.

Pitelis, C. (2002). On economics and business ethics. Business Ethics: A European Review, 11(2), 111118. https://doi.org/10.1111/1467-8608.00265

Rahner, K. (1970). The Trinity. New York: Herder and Herder.

Rudnyckyj, D. (2010). Spiritual Economies (1st ed.). USA: Cornwell University Press.

S. C. Schneider, \& Barsoux, J. (2003). MAanaging Across Cultures (2nd ed.). New Jersey: Prentice Hall.

Sanders, F. (2001). Entangled in the Trinity: Economic and Immanent Trinity in Recent Theology. Dialog: A Journal of Theology, 40(3), 175-182. https://doi.org/10.1111/0012-2033.00073

Stamatoviĉ, S. (2016). The meaning of perichoresis. Open Theology, 2(1), 303-323. https://doi.org/10.1515/opth-2016-0026 